sent chemical individuals, though whether they were originally present in the thyroid or were formed during subsequent treatment of the tissue has yet to be determined with certainty.

In any event the results obtained in this first experiment make it appear likely that with further improvements in technique a valuable new tool for the study of intermediary metabolism will be established. The final elucidation of the possible significance of these data with respect to thyroid physiology will probably require more work than we are in a position to undertake in the immediate future. It is for this reason, and with the hope that the technique may be of value to other investigators, that the results are being reported in the present incomplete form.

${ }^{1}$ Consden, R., Gordon, A. H., and Martin, A. J. P., Biochom. J., 38 224 (1944).

' Dent, C. E., Biochem. J., 41, 240 (1947).

Partridge, S. M., Nature, 158, 270 (1946).

\section{BRITISH SOCIAL HYGIENE COUNCIL}

\section{INTERNATIONAL SCHOOL IN SOCIAL BIOLOGY}

$\mathrm{T}$ HIS year the British Social Hygiene Council held its first international school in social biology at Berne, Switzerland, during August 21-September 4. The school was attended largely by teachers and welfare-workers, most of whom came from Great Britain, although a few from other nations gave enhanced interest to the proceedings. It was planned to be a blend of work and pleasure, the first week being devoted to regular lecture-sessions, and the second to excursions and personal recreation. The members were housed in groups in various hotels in Berne, while all meetings were held in the University buildings, where lecture-room accommodation had been placed at the Council's disposal free of cost.

The lectures and discussions were held in English. For the ordinary morning sessions the Council took out a staff from England; during the evenings the School had the privilege of hearing addresses by Swiss men of science and social workers. Prof. P. B. Medawar gave a series of lectures concerned with the principles of pure biology. In succession, he spoke on "Growth", "The Theory of Evolution from a Modern Standpoint", "Ageing in Individuals", and "Adaptation and Directive Behaviour". He was at pains to emphasize the comparative aspects of organic development, which he interpreted on modern genetical lines. Everyday problems of psychology at different stages in life were presented in four lectures by Dr. Mary Smith. Her subject-matter formed an integrated whole which served to give those who had had little previous experience of psychology a clearer understanding of its scope and method as well as insight into individual problems of their own.

Reflecting more directly the particular outlook of the British Social Hygiene Council, Mr. R. Weatherall spoke on "The Creative Mission of Social Biology", "The Human Family in a Changing Environment", "Some Implications of Modern Concepts of Race", and "The Human Aspects of Evolution". In choosing these subjects for his lectures his intention was to direct interest to broad problems of public concern in which social biology finds important applications which cannot be ignored. Further individual lectures were given by Miss M. M. West on "The Public Health Nurse and the Family Unit", and by Miss J. E. R. Kennedy on "The Police Court and the Community". Two informal Sunday meetings on the relationships between social biology and spiritual values led to a useful exchange of views, but served to show that on such a wide subject and without outside direction the method of open discussion does not take one very far.

Among the visiting speakers, the British Social Hygiene Council owes a special debt of gratitude to Dr. H. Revilliod for his invaluable help and advice. In his address on "Some Ways of Facing Social Evils in Switzerland" he explained. how through careful organisation his country had been shielded from serious epidemics of infectious disease throughout all the disturbances of the war-time years. He referred to very satisfactory results now being obtained in the treatment of tuberculosis, and to the advantages of occupying the patients with gainful work. He also referred to the change in public attitude towards drunkenness in Switzerland, where even in the penal code it is recognized that heavy drinkers are sick members of society and in neod of special care. His lecture ended with a description of the great success which has been attained in the prevention of endemic goitre by the addition of small amounts of potassium iodide to household salt. In earlier times the disease was very widespread in certain areas, giving rise to many cretinous and backward children, a number of whom were mute and deaf; now among young children it has disappeared.

Dr. St. Zurukzoglu contributed a paper on "Social Psycho-Hygiene". It was interesting to find that quite independently and through his own work he has arrived at a conception of social biology similar to that of the British Social Hygiene Council. In his view, organic factors, heredity, environmental influences and psychological dispositions were all contributory agents in the causation of disease. To cure the spiritually sick seemed to him as important as to heal the physically unwell, and he called for a medical pastoral service to work alongside that based on religion.

Dr. E. R. Frey of the Staatsanwalt gave a particularly stimulating address on "Biology and Juvenile Delinquency". Basing his argument on the theme that the treatment of juvenile delinquency is the foundation for all prevention of crime, he made it clear that only about 25 per cent of young offenders grow up into confirmed criminals. Members of this special group show serious abnormalities of a psychological nature and are often of low mental ability at the same time. As predisposing influences in the causation of crime, constitutional factors seem much more important than environmental conditions. The conclusion to which Dr. Frey's thosis led was that the treatment of young offenders should be based upon their biological circumstances and not upon the nature of their deed.

During the School, and in addition to excursions to some of the scenic attractions of Switzerland, visits were paid to certain departments of the hospital quarter at Berne, Kindergarten and other educational institutions, a housing estate, the international Pestalozzi school for refugee children at Trogen, the cantonal agricultural school at Rüti, and La Nuch. tern, a home for the treatment of drunkards. Through the kind offices of Dr. V. J. Steiger, members of the 
School were also able to see two films, the first dealing with the problem and treatment of drunkenness in Switzerland, and the second with the utilization of fruit, either in a fresh or preserved state, for human consumption or as a source of unfermented juices which can be made into most attractive drinks the popularity of which is increasing year by year.

R. WEATHERALL

\section{CO-OPERATION IN BOTANICAL RESEARCH}

$F^{\circ}$ OR his presidential address to the Botanical Society of America (December 28, 1946), Dr. I. W. Bailey, chairman of the Institute for Research in Plant Morphology at Harvard University, selected the theme of "Co-operation Versus Isolation in Botanical Research" (Chronica Botanica, 11, 1947).

In a world subject to profound and drastic changes, Dr. Bailey considers it inevitable that botanical science must also be affected, particularly the older branches of the subject. To quote his own words, he raises "the challenging question, what roles should taxonomy, anatomy, palæobotany and other phases of morphology be expected to play in future developments ?". A whole book could be devoted to the answer. Certainly the way has been prepared for a brisk and lively discussion.

"There are, of course, two extreme views regarding the matter. On the one hand, there are individuals who believe that these largely descriptive disciplines are moribund, if not actually over-ripe for interment, and that funds now dissipated for their support should be diverted into productive ultra-modern, experimental channels. On the other hand, there are those laissez-faire individuals who naively assume that civilization must continue to support their endeavours regardless of how unproductive their viewpoints and methodologies may have become.

"The latter individuals are living in a dream world of their own creation which is destined sooner or later to be rudely shattered. The former individuals fail to visualize the extreme complexity and variability of biological phenomena, and thus overlook or ignoro numerous significant morphological variables in their experimental material."

In the first place, he asks if the extensive morphological researches of the last hundred years have not provided sufficient data to serve the purposes of contemporary and future experimental disciplines, in particular, those of the physiologist, the biochemist and the biophysicist. When these workers turn to the standard texts, can they find in them the information which they require? Dr. Bailey replies in the negative, and in this he will be supported by most botanists who have given thought to the matter. Many of the supposedly fundamental ideas of plant anatomy are inadequate, based as they were on researches undertaken in relation to phylogenetic questions. An impartial consideration of almost any of the major problems of contemporary interest will reveal how much scope still remains for morphological inquiry. To quote Dr. Bailey : "It is evident that significant progress in the solution of important botanical problems is being retarded by inadequacies of existing morphological data and by the unquestioning acceptance of unreliable generalizations". He then asks how these difficulties are to be avoided in the future, and emphasizes the dangers and draw. backs of premature specialization in instruction and research. "This encystment of botany in specialized subdivisions encourages premature and excessive generalizations from limited induction and tends to inhibit unified attacks along broad fronts, such as are essential for the solution of the more complex and difficult types of botanical problems." The solution of any of the major problems of biology requires the close co-operation of workers in different fields and a harmonizing of the data of the several contributory disciplines. Various means are available whereby co-operation can be encouraged, but as to how the latter aim is to be achieved Dr. Bailey is rather less specific. The magnitude of the task is oppressive : in practice it will call for the sustained activities of a team of workers. Yet, as experience teaches, major biological syntheses depend on the special qualities and capacities of particular individuals, and these, apparently, are of rare and sporadic occurrence.

Morphologists, whether adherents of old or new conceptions, are not alone in being scourged by Dr. Bailey. "If one probes deeply into the applications of physics and chemistry in the analysis of plant materials one likewise finds evidences of premature and excessive generalization from restricted viewpoints. I have encountered this tendency in exaggerated form in chemical analysis of plant tissues and particularly in physical and chemical investigations of the walls of plant cells. The specialist in specific physical and chemical methodologies is likely to run astray unless his deductions are verified by individuals who are thoroughly familiar with the full complex of structural variables in a wide range of plants."

But Dr. Bailey is by no means pessimistic in his outlook for plant morphology. He views with confidence a future in which taxonomy, anatomy and other morphological disciplines will be stimulated and broadened by close contact with one another and with other branches of the science. The result should be a closer approach to the solution of the central problems of biology. "To facilitate such mutually beneficial relationships, it is essential to break down existing emotional and intellectual barriers." The morphologist must recognize the limitations of his own techniques and appreciate the assistance which other disciplines can afford him in solving problems in his own particular field. "He must acquire sufficient familiarity with chemistry and physics to enable him to talk intelligently with workers in other disciplines." In emphasizing this point, Dr. Bailey's observations are no doubt pertinent in relation to some of the research institutions in the United States : in a majority of British universities, a reasonable knowledge of chemistry and physios is now regarded as an essential preparation for botanical studies.

A particular interest is attached to that section of the address in which Dr. Bailey attempts to show how co-operation between the different subdivisions of botany is to be achieved. "It cannot be coerced or developed directly by administrative fiat. It must arise naturally and more or less spontaneously or not at all. The wisest and most effective procedure should be to create a general environment that encourages rather than inhibits co-operative efforts." To some extent this can be achieved by wise administration, particularly by making suitable appointments and the judicious allocation of funds. An allocation of funds which tends to encourage excessive diversification and specialization and which favours 